\title{
Foreign and domestic shocks: macroeconomic responses of ASEAN-3 countries
}

\begin{abstract}
The study provides new empirical evidence on the relative importance of foreign and domestic shocks on selected ASEAN-3 (Malaysia, Indonesia, and Thailand) macroeconomic variables. Three structural vector auto regression models are estimated for each country. The focal point is given on the formulation of the sources of foreign factors. The first model uses trade-weighted foreign variables of both US and Japan to represent the foreign factors. The other two models use US and Japan by themselves, respectively, to represent the foreign factors. Two important results are emerged. First, foreign sectors play an important role in influencing macroeconomic variables of each of the ASEAN-3 country, especially in the medium and the long-run horizon. Second, most of the time, the Japanese factors are more dominant than the US factors in influencing domestic output and inflation for each of the ASEAN-3 countries.
\end{abstract}

Keyword: Structural vector autoregressive (SVAR) model; Foreign shocks; Monetary policy 